HUMANITAS, Vol.15, No.1, Februari 2018, Hal. 35 - 45

\title{
PENINGKATAN CAREER DECISON MAKING SELF EFFICACY (CDMSE) MELALUI PELATIHAN PERENCANAAN KARIR PADA SISWA SMK
}

\author{
Devi Damayanti ${ }^{1}$, Arini Widyowati ${ }^{2}$ \\ Fakultas Psikologi Universitas Ahmad Dahlan \\ Jl. Kapas no 9 Semaki Yogyakarta 55166 \\ 1devi.damayanti@psy.uad.ac.id
}

\begin{abstract}
One of the developmental task of teenager at senior high school is to determine their future career choice. The present research aimed to examine the effect of career planning training on studens's career decision making self efficacy (CDMSE). This study that involved 36 vocational high school students from two class of administrasi perkantoran department in SMK Negeri 1 Bantul Yogyakarta. Subjects were divided into two groups as experiment group and control group through cluster random sampling. Data was collected using CDMSE scale and was analyzed by Anova Mixed Design. Results showed that there was a significant increasing of CDMSE on experiment group and insignificant ones in control group after training was given. Career planning training was effective to increase student's career decision masking self-efficacy. Discussions and recommendations are discussed further.
\end{abstract}

Keywords: career decision making self efficacy, career choice, career planning, intervention.

\begin{abstract}
Abstrak
Salah satu tugas perkembangan remaja pada jenjang pendidikan menengah atas adalah menentukan pilihan karir masa depannya. Penelitian ini bertujuan untuk mengetahui pengaruh pelatihan perencanaan karir terhadap peningkatan career decision making self efficacy (CDMSE) pada siswa SMK. Peneliti menggunakan metode kuasi-eksperimen yang melibatkan subjek penelitian sebanyak 36 siswa Negeri 1 Bantul jurusan administrasi perkantoran. Subjek dikelompokkan menjadi kelompok eksperimen dan kelompok kontrol. Pengumpulan data menggunakan skala CDMSE dan dianalisis menggunakan teknik analisis Anova Mixed Design dengan bantuan spss 2.3 for windows. Hasil analisis menunjukkan bahwa ada perbedaan tingkat efikasi diri dalam pengambilan keputusan karir antara kelompok eksperimen dan kontrol. Peningkatan CDMSE terjadi pada kelompok eskperimen dan tidak perubahan pada kelompok kontrol. Hasil analisis juga menujukkan bahwa rerata post test pada kelompok eksperimen lebih tinggi dibandingkan pre test. Hal ini menunjukkan bahwa pelatihan perencanaan karir cukup efektif
\end{abstract}


meningkatkan CDMSE pada siswa SMK. Pelatihan perencanaan karir memberikan sumbangan sebesar 58,1\% terhadap peningkatan CDMSE pada siswa SMK.

Kata kunci: career decision making self efficacy, intervensi, perencanaan karir, pilihan karir

\section{Pendahuluan}

Seiring dengan pertumbuhan ekonomi yang cepat, ketersediaan tenaga kerja yang siap dan sesuai dengan kebutuhan pasar menjadi tantangan bagi dunia pendidikan di Indonesia. Institusi pendidikan diharapkan mampu menghasilkan lulusan yang kompeten dan berdaya saing tinggi. Salah satu institusi pendidikan yang diharapkan dapat menyediakan tenaga kerja yang handal dan terampil adalah Sekolah Menengah Kejuruan (SMK). SMK adalah salah satu jenjang pendidikan menengah yang dengan kekhususan mempersiapkan lulusannya untuk siap bekerja. Lulusan SMK diharapakan mampu terserap dan berperan besar dalam dunia kerja. Akan tetapi pada kenyataannya masih banyak lulusan SMK yang belum sepenuhnya terserap di dunia kerja. Berdasarkan Data dari data Badan Pusat Statistik (BPS) Tingkat Pengangguran Terbuka (TPT) pada lulusan SMK di Indonesia sampai bulan November 2017 mencapai 11,41\% paling tinggi di antara lulusan pada jenjang pendidikan yang lain. Tingginya angka pengangguran lulusan SMK dimungkinkan berhubungan dengan kesulitan dalam menentukan pilihan karirnya. Penelitian yang dilakukan oleh Juwitaningrum (2013) menunjukkan bahwa masih banyak siswa SMK yang tidak yakin dengan pilihan karirnya.

Pemilihan karir merupakan salah satu keputusan paling penting dalam kehidupan individu. Keputusan mengenai karir melibatkan banyak faktor yang membentuk jalur dalam dalam diri individu. Menurut Baruch (2004), karir membuat individu mampu memenuhi kebutuhan dasar dan memberikan kesempatan untuk memenuhi kebutuhan ditingkat yang lebih tinggi. Karir juga merupakan bagian dari pencapaian tujuan, tantangan, pemenuhan dan pengembangan diri yang membuat individu mampu berpartisipasi dalam lingkungan. Karir juga merupakan sumber identitas diri, dimana individu dapat mengembangkan kreativitas dan keahlian.

Pemilihan karir berhubungan dengan pekerjaan yang akan dilakukan oleh individu. Dalam tahapan perkembangannya, penyesuaian dengan pekerjaan merupakan salah satu tugas perkembangan yang harus dilalui individu ketika memasuki usia dewasa awal (Hurlock, 1994). Penyesuaian awal yang dianggap penting adalah memilih bidang pekerjaan yang cocok dengan bakat, minat dan faktor pikologis lainnya. Dalam banyak kasus, individu lebih memilih karir karena pengaruh sosial yang ada dan bukan dipengaruhi oleh bakat dan minatnya. Hal ini menimbulkan adanya ketidakpuasan terhadap kinerjanya, tidak mencintai tugas dan akhirnya berdampak pada penurunan prestasi kerjanya.

Sehubungan dengan hal tersebut, beberapa individu telah menentukan pilihan karirnya jauh-jauh hari sebelum mereka bekerja dan telah melatih diri sesuai dengan persyaratan yang diperlukan sesuai dengan jenis tugas yang dianggap sesuai dengan minat dan bakatnya. Disisi lain masih banyak juga individu yang mengalami kebingunan dengan apa yang akan mereka kerjakan dalam hidupnya setelah menyelesaikan sekolah tingkat atas 
(SMA), akademi bahkan perguruan tinggi (Hurlock, 1994). Sebagian individu terutama pada usia sekolah kurang mampu mengeksplorasi diri dan lingkungan yang menyebabkan kurangnya pemahaman mengenai kesempatan kerja dan informasi yang akurat mengenai kesempatan pekerjaan yang membantu individu untuk menentukan pilihan karir yang tepat (Zeibel, 2010).

Pemilihan bidang kerja, jurusan yang sesuai dengan bakat dan minat, atau kurikulum yang berisi kebutuhan yang diperlukan untuk bekerja manjadi semakin sulit ditemukan oleh setiap tingkat generasi berikutnya (Hurlock, 1994). Perubahan yang cepat, ketidakstabilan dan perubahan di era teknologi informasi menyebabkan pengambilan keputusan pada suatu pekerjaan tertentu menjadi sesuatu yang sulit. Perubahan tersebut berdampak pada perkembangan peran, tanggung jawab dan identitas suatu pekerjaan yang mungkin tidak terbayangkan oleh individual di awal karirnya (Zeibel, 2010). Sejalan dengan perubahan dunia usaha yang semakin kompleks dengan pilihan yang semakin individu tidak hanya dituntut untuk merencanakan karirnya namun juga melakukan kajian mengenai karir sebelum menentukan pilihan sehingga mampu menyesuaikan diri dengan kondisi sosial ekonomi.

Pengambilan keputusan karir berhubungan dengan kepercayaan diri dalam mengambil keputusan yang dikenal dengan istilah Career Decision Making Self Efficacy (CDMSE). CDMSE adalah derajat keyakinan individu terkait dengan harapan tentang diri atau kemampuannya untuk melakukan tugas-tugas tertentu dan perilaku-perilaku yang penting sehingga dapat dengan sukses menghubungkan kaitan tugas-tugas tersebut dengan sebuah tujuan karir (Betz, \& Luzzo, 1996). Tingginya keyakinan diri akan keputusan karir mempertinggi penggunaan program panduan karir langsung secara mandiri yang terkomputerisasi (Fukuyama, Probert, Neimeyer, Nevill \& Metzler, 1988). Rendahnya CDMSE juga berhubungan dengan tingginya burnout yang dalam jangka panjang berdampak pada konflik antar pekerja, penurunan produktivitas serta keinginan untuk keluar dari pekerjaan (turnover) (Schwarzer \& Hallum, 2008). Rendahnya CMDSE pada siswa dapat mengganggu upaya eksplorasi karir dan pengembangan kemampuan pengambilan keputusan karir yang berdampak pada kebimbangan karir dan permasalahanpermasalahan lain dalam pengambilan keputusan karir dimasa depan (Matsui \& Onglatco, 1992) serta kecemasan atas proses pemilihan karir (Bandura, 1997).

Senada dengan hasil penelitian tersebut, Taylor dan Popma (1990) menemukan bahwa CDMSE menjadi salah satu prediktor yang paling signifikan terhadap keraguan dalam pemilihan jurusan siswa. Hasil penelitian lain menunjukkan semakin tinggi tingkat CDMSE siswa akan mempengaruhi konsep karir dan eksplorasi karir yang dilakukan oleh siswa (Gushue, Scanlan, Pantzer \& Clarke, 2006). Oleh karenanya, perlu upaya agar siswa dapat memiliki level CDMSE yang tinggi atau memadai agar dapat menetapkan pilihan karir atau jurusan dengan lebih percaya diri.

Dalam tahap perkembangan karir, usia sekolah menengah atas berada pada tahap eksplorasi. Menurut Sawitri (2009) masa ekplorasi ini bertujuan untuk menentukan alternatif-alternatif dalam tiap domain yang akan diterapkan individu pada masa selanjutnya. Eksplorasi yang dilakukan dan komitmen yang dibuat dalam beragam domain kehidupan, membuka peluang bagi siswa untuk memperoleh sumber-sumber informasi efikasi diri yang dibutuhkannya untuk membentuk keyakinan dalam melakukan tugas-tugas terkait dengan keputusan karir. Menurut Caprara, Scabini, dan Regalia (2006) efikasi diri 
merupakan hasil dari berbagi pengetahuan dan tanggungjawab, hubungan yang beragam, tugas-tugas yang bermanfaat, dan interaksi dengan orang lain. Penelitian Wang, Zang, dan Shao (2010) yang menemukan bahwa konseling kelompok dalam karir mampu meningkatkan CDMSE pada mahasiswa Southwest University di Cina. Sementara menurut Seo dan Jeong (2016), program pelatihan karir pada siswa sekolah perawat dapat meningkatkan level CDMSE siswa. Kraus dan Kenneth (1999) juga mengemukakan perlunya intervensi berupa pendampingan kepada siswa dalam perencanaan karir mereka untuk meningkatkan level CDMSE siswa dan menurunkan keraguan karir yang dirasakan.

Perencanaan karir adalah sebuah proses yang tidak singkat. Menurut Bardick, Berrnes, Magnusson, dan Witko (2004), perencanaan karir adalah sebuah proses yang dimulai ketika individu mulai mengeksplorasi kemampuan, nilai-nilai, minat dan peluang mereka dalam persiapan eksplorasi karir. Perencanaan karir sendiri bertujuan untuk mengidentifikasi kebutuhan-kebutuhan, aspirasi-aspirasi dan peluang-peluang karir bagi individu serta implementasi program-program manajemen sumberdaya manusia untuk mendukung karir (Antoniu, 2010). Secara lebih spesifik, menurut Edgar Schein (dalam Manolescu, 2003) perencanaan karir adalah proses yang berkesinambungan dalam pencarian seorang individu terkait konsep pekerjaan sebagai hasil ketrampilan, kemampuan, kebutuhan, motivasi dan aspirasi dari system nilai individu. Perencanaan karir dipandang sebagai sebuah proses yang sistematis dan komprehensif dalam pengembangan karir yang dituju dan implementasi sejumlah strategi, asesmen diri dan analisis berbagai peluang serta evaluasi hasilnya.

Berdasarkan uraian tersebut, diperlukan adanya upaya peningkatan keterampilan perencanaan karir bagi siswa SMK sehingga dapat mendukung effikasi dirinya dalam menentukan pilihan karir. Pelatihan perencanaan karir akan mendukung kemampuannya dalam melakukan ekplorasi mengenai diri dan kesempatan karir serta mampu menyusun perencanan karir yang menjadi tujuannya. Perencanaan karir yang dipersiapkan dengan baik akan mendukung keyakinan yang tinggi terhadap pengambilan keputusan karirnya. Lebih jauh lagi, setelah siswa mampu mengambil keputusan karirnya, diharapkan mereka memiliki ketramilan dalam menentukan target dan menyusun rencana tindakan untuk mencapai tujuan karirnya. Tidak hanya bagi siswa, penelitian ini diharapkan juga bermanfaat bagi pihak sekolah untuk membantu merancang intervensi yang dapat membantu siswa untuk lebih percaya diri dalam merencanakan karirnya di masa yang aakan dating.

\section{Metode Penelitian}

Subjek penelitian ini adalah siswa laki-laki dan perempuan kelas XI SMK Negeri 1 Bantul jurusan administrasi perkantoran (AP) yaitu kelas AP 1 dan kelas AP 2. Subjek kemudian di bagi dalam dua kelompok yaitu kelompok kontrol sejumlah 13 orang dan kelompok eksperimen sejumlah 23 orang. Pembagian kelompok penelitian berdasarkan kelas karena tidak dimungkinkan dilakukan pengelompokkan secara random sehingga terpilih kelas AP.1 sebagai kelompok eksperimen dan kelas AP 2 sebagai kelompok kontrol. 
Desain penelitian yang digunakan dalam penelitian ini adalah pretest-posttestfollow up, control group design, sebagaimana tersaji dalam gambar 1. Dalam desain ini efek suatu perlakuan terhadap variabel dependen akan diuji dengan cara membandingkan keadaan variabel dependen pada kelompok eksperimen setelah dikenai perlakuan dengan kelompok kontrol yang tidak dikenai perlakuan. Perlakuan pada kelompok ekperimen berupa pelatihan perencanaan karir.

Gambar 1. Rancangan Eksperimen.

\begin{tabular}{|c|c|c|c|c|}
\hline & $\mathrm{Ge}$ & $\mathrm{O}_{1}$ & $X$ & $\mathrm{O}_{2}$ \\
\hline & Gk & $\mathrm{O}_{1}$ & - & $\mathrm{O}_{2}$ \\
\hline Ket & gan: & & & \\
\hline $\mathrm{Ge}$ & : Grup eksperimen & & & \\
\hline Gk & : Grup kontrol & & & \\
\hline$X$ & : Perlakuan ( Pelatih & seren & aan & \\
\hline$(-)$ & : Tanpa perlakuan & & & \\
\hline $\mathrm{O}_{1}$ & : Pretest & & & \\
\hline $\mathrm{O}_{2}$ & : Post test & & & \\
\hline
\end{tabular}

Materi pelatihan perencanaan karir terdiri atas lima kompetensi yaitu pengenalan dan pemahaman potensi diri, pegumpulan informasi secara mandiri, kemampuan menetukan pilihan karir berdasarkan pemahaman akan informasi yang dikumpulkan dan pemahaman akan potensi diri, kemampuan menetapkan tujuan dan membuat perecanaan karir serta problem solving. Materi ini diberikan kepada kelompok eksperimen untuk meningkatkan keyakinan diri siswa dalam menentukan tujuan karirnya. Untuk menjaga moral subjek, pada kelompok kontrol diperlakukan sebagai kelompok tunggu, yang diberikan perlakukan setelah pengukuran selesai dilakukan. Perlakukan yang diberikan berupa pelatihan perencanaan karir sebagaimana yang diberikan pada kelompok eksperimen. Setelah perlakukan diberikan tidak dilakukan pengukuran, sehingga tidak mempengaruhi hasil pengukuran sebelumnya.

Prosedur eksperimen dilakukan melalui beberapa tahap yaitu dimulai dari (1) analisa kebutuhan pelatihan, ini dilakukan untuk mengetahui sejauh mana pemahaman subjek mengenai karir dan menentukan materi dan metode intervensi yang akan dilakukan; (2) sosialisasi dan pemberian informed concern pada subjek; (3) pengukuran CDMSE sebelum perlakukan atau pre test; (4) perlakukan pada kelompok eksperimen (4) pengukuran setelah pelatihan atau post test; (5) Pengukuran follow up; (6) pemberian pelakuan kepada kelompok kontrol.

Data diperoleh dengan menggunakan metode pengumpulan data berupa skala. Skala yang digunakan dalam penelitian ini adalah skala career decision making self-efficacy dengan model Likert bentuk. Skala ini merupakan modifikasi dari skala CDMSE (Career Decision Making Self Efficacy) yang dibuat olah Betz dan Taylor (2012) versi pendek yang terdiri atas 25 item. Berdasarkan hasil ujicoba yang dilakukan, didapatkan skala CDMSE memiliki rentang indeks daya beda item bergerak dari 0,320 sampai 0,695. Skala ini juga 
memiliki koefisien reliabilitas alpha $(\alpha)$ sebesar 0,904 artinya skala tersebut handal dan dapat digunakan sebagai alat pengumpul data dalam penelitian. Teknik analisis data yang akan digunakan untuk pengujian hipotesis penelitian ini adalah uji statistik analisis Anava Mixed Design dengan menggunakan SPSS 23.0 for windows.

\section{Hasil dan Pembahasan}

Tabel.1

Deskriptif Statistik Skor CDMSE

\begin{tabular}{lllrl}
\hline & \multicolumn{1}{c}{ Grup } & Mean & \multicolumn{1}{c}{ SD } & N \\
\hline Pretest & Eksperimen & 74,35 & 8,111 & 23 \\
& Kontrol & 76,31 & 10,912 & 13 \\
& Total & 75,06 & 9,115 & 36 \\
\hline Posttest & Eksperimen & 92,65 & 16,174 & 23 \\
& Kontrol & 78,62 & 9,278 & 13 \\
& Total & 87,58 & 15,515 & 36 \\
\hline Follow up & Eksperimen & 86,87 & 12,603 & 23 \\
& Kontrol & 80,38 & 15,452 & 13 \\
& Total & 84,53 & 13,845 & 36 \\
\hline
\end{tabular}

Berdasarkan data, terlihat bahwa terjadi perubahan skor rata-rata CDMSE sebelum pelatihan, setelah pelatihan dan follow up baik pada kelompok eksperimen maupun kelompok kontrol. Sebelum pelatihan skor rata-rata CDMSE pada kelompok eksperimen sebesar 74, 35 dan mengalami peningkatan yang cukup signifikan hingga mencapai 92.85 setelah diberikan pelatihan. Meskipun demikian mengalami penurunan menjadi 86,87 pada pengukuran follow up. Peningkatan rata-rata skor CDMSE pada kelompok kontrol juga mengalami peningkatan dari sebelum pelatihan dari 76,31 ke 78,62 setelah pelatihan hingga 80,38 pada pengukuran follow up

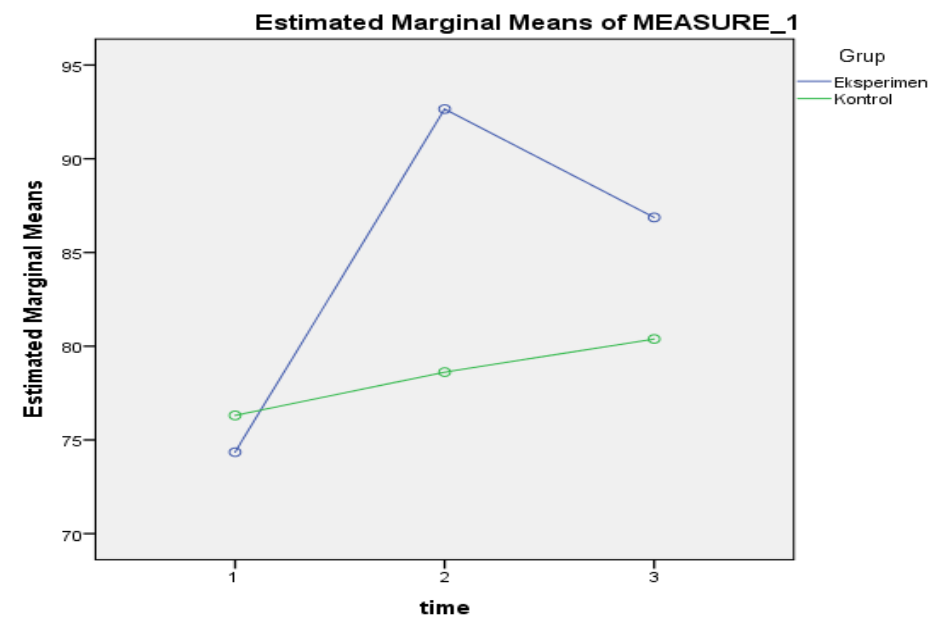

Gambar 1. Rata-rata Skor CDMSE pada kelompok eksperimen dan Kelompok Kontrol

Keterangan:

1 pre test 
2 post test

3 follow up

Sebagaimana di tunjukkan pada gambar 2, terlihat bahwa tidak terdapat perbedaan skor rata-rata CDMSE yang signifikan pada kelompok eksperimen maupun kelompok kontrol sebelum pelatihan diberikan. Skor rata-rata pada kelompok eksperimen mengalami peningkatan skor rata-rata hingga mencapai 92,85 setelah pelatihan, meskipun mengalami penurunan pada pengukuran follow up pada 86,87. Pada kontrol, tidak terjadi perubahan skor rata-rata yang berarti sebelum pelatihan ke setelah pelatihan diberikan maupun pada pengukuran follow up. Secara berurutan skor rata-rata bergerak dari 76,31 ke 78,62 hingga 80,38 .

Tabel. 2

Hasil Uji Hipotesis

\begin{tabular}{lllcc} 
Grup & $(\mathrm{I})$ time & $(\mathrm{J})$ time & Mean Difference $(\mathrm{I}-\mathrm{J})$ & Sig. $^{\text {b }}$ \\
\hline Eksperimen & 1 & 2 & $-18,304^{*}$ &, 000 \\
& & 3 & $-12,522^{*}$ &, 000 \\
& 2 & 1 & $18,304^{*}$ &, 000 \\
& & 3 & 5,783 &, 051 \\
& 3 & 1 & $12,522^{*}$ &, 000 \\
Kontrol & 1 & 2 & $-5,783$ &, 051 \\
& & 2 & $-2,308$ &, 527 \\
& 2 & 1 & $-4,077$ &, 295 \\
& & 3 & 2,308 &, 527 \\
& 3 & 1 & $-1,769$ &, 645 \\
& & 2 & 4,077 &, 295 \\
& & 2 & 1,769 &, 645 \\
\hline
\end{tabular}

Keterangan

1: Pre test

2. Post test

3. Follow up

Hasil dari uji hipotesis menunjukkan adanya perubahan CDMSE pada kelompok eskperimen signifikan dengan $\mathrm{MD}=-18,304, \mathrm{P}<0,005$. Sedangkan perubahan pada kelompok kontrol tidak signifikan dengan $\mathrm{MD}=-2,308 ; \mathrm{P}>0,05$. Hal ini menunjukkan bahwa pelatihan perencanaan karir cukup efektif meningkatkan CDMSE pada siswa SMK. Hasil analisis juga menujukkan bahwa rerata post test pada kelompok eksperimen lebih tinggi dibandingkan pre test. Artinya terjadi peningkatan yang CDMSE pada subjek sebelum dan setelah pelatihan. Berdasarkan hasil analisis multivariate test diperoleh nilai partial eta square pada kelompok eksperimen sebesar 0,581 artinya, pelatihan perencanaan karir memberikan sumbangan sebesar 58,1\% terhadap peningkatan CDMSE pada kelompok eksperimen. Hal ini menunjukkan bahwa pelatihan perencanaan karir efektif untuk meningkatkan CDMSE siswa.

Hasil penelitian ini sejalan dengan dengan penelitian sebelumnya yang dilakukan oleh Wang, et al. (2010), dinyatakan bahwa (group training) konseling karir kelompok berpengaruh secara signifikan terhadap peningkatan CDMSE kelompok eksperiman. Juga 
hasil penelitian Seo dan Jeong (2016) serta Kraus dan Hughey (1999) yang menemukan bahwa intervensi yang diberikan pada siswa untuk melakukan perencanaan karir terbukti dapat meningkatkan level CDMSE siswa. Career decision making self efficacy secara sederhana adalah keyakinan diri untuk melakukan pengambilan keputusan karir. Menurut Bandura (1997) efikasi diri individu dapat dipenguruhi oleh empat sumber informasi yaitu: (a) pencapaian kinerja / prestasi, pengalaman keberhasilan individu dalam menjalankan tugas tertentu, (b) modeling, (c) persuasi verbal, yaitu dorongan atau dukungan dari pihak lain dan (d) tingkat kesiapan fisik dan psikologis individu pada perilaku tertentu. Pengelaman keberhasilan merupakan sumber informasi yang paling berpengaruh terhadap efikasi diri individu.

Pelatihan perencanaan karir memberikan keterampilan pada siswa untuk mengekplorasi diri dengan cara melakukan refleksi atas keberhasilan dan kegagalan, kelemahan dan potensi yang dimiliki baik yang berasal dari diri sendiri maupun umpan balik dari pihak lain terutama umpan balik dari significant person. Pemahaman akan diri akan mendorong penerimaan terhadap diri sendiri. Pemahaman akan pengalaman keberhasilan dan meningkatkan kesadaran akan potensi diri akan meningkatkan keyakinan siswa terhadap kemampuannya. Disisi lain, pemahaman akan kegagalan atau keterbatasan diri akan mendorong penerimaan individu akan keterbatasannya sehingga dapat memotivasi dan melakukan usaha - usaha untuk mengatasi keterbatasan yang dimiliki.

Sumber informasi lain yang mempengaruhi efikasi diri adalah modeling. Semakin besar kemiripan model dengan individu, akan semakin mempersuasi individu. Dalam pelatihan perencanaan karir, subjek diberikan pemaparan dan serangkaian tugas mengenai keberhasilan alumni SMK. Persepsi akan kesamaan sebagai siswa SMK dapat membangun kesadaran subjek akan potensi dan harapan yang akan dicapaikan. Dalam pelatihan subjek juga mendapatkan sumber informasi berupa persuasi dari trainer maupun dari subjek lain mengenai tujuan karirnya.

Menurut Bandura (1997) efikasi diri akan meningkat jika target perilaku realistis dengan kemampuan yang dimiliki. Pelatihan perencanana karir memberikan keterampilan kepada siswa untuk menentukan tujuan karir yang realistis dan menentukan langkahlangkah yang sistematis untuk mencapai tujuan. Sumber informasi lain yang dapat mempengaruhi efikasi diri adalah rendahnya tingkat kecemasan terhadap perilaku tertantu. Pelatihan perencanaan karir membantu subjek mengidentifiksi potensi hambatan yang mungkin muncul dalam pencapaian tujuan karir. meskipun dekimian, pada sesi goal setting dan rencana tindakan, subjek diberikan keterampilan untuk membuat perencanan dan merumusan rencana tindakan untuk mengatasi hambatan.

Pengambilan keputusan sangat dipengaruhi oleh ketersediaan informasi. Dalam pelatihan perencanaan karir, subjek diberikan keterampilan untuk mengumpulkan informasi dan melakukan analisa atas informasi yang ada terkait dengan potensi diri dan peluang karir. Subjek diberikan penugasan untuk mengumpulkan informasi terkait kelebihan, kelemahan, hobi, minat, pegetahuan, keterampilan serta kemampuan spesifik yang dimiliki. Subjek juga diberikan penugasan untuk mengumpulkan informasi mengenai berbagai alternatif pilihan karir terkait dengan tugas, aktivitas serta kompetensi yang dibutuhkan dalam setiap pilihan karir. Menurut Robbins (2003) semakin lengkap informasi yang ada, semakin mudah bagi individu dalam menentukan pilihannya dan mengambil keputusannya. 
Tahap berikutnya dalam pengambilan keputusan adalah penentuan kriteria. Dalam sesi pengambilan keputusan karir subjek menentukan kriteria dan pembobotan tiap kriteria yang menjadi pertimbangan dalam pilihan karirnya. Bedasarkan kriteria dan pembobotan tersebut subjek menentukan beberapa alternatif pilihan karir. Berdasarkan hasil perhitungan dan pembobotan subjek dapat menentuka pilihan karir yang optimal. Berdasarkan hasil analisis pada lembar kerja pengambilan keputusan, kesesuaian minat dan kemampuan serta pendapatan menjadi kriteria penting dalam pemilihan karir pada siswa SMK.

Beberapa penelitian mengenai pelatihan terkait karir pernah dilakukan oleh banyak peneliti. Purnamasari (2006) mengemukakan bahwa metode pelatihan sangat bermanfaat dalam merencanakan karir. Hasil penelitian menyatakan bahwa sebuah pelatihan perencanaan karir memberikan sumbangan sekitar $65 \%$ dalam meningkatkan kejelasan arah pilihan bidang minat karir. Upaya intervensi pada peningkatan career decision making self efficacy juga pernah dilakukan pada siswa seperti yang dilakukan oleh Wang, Zang, dan Shao (2010); Seo dan Jeong (2016) Kraus dan Hughey (1999); serta Ariani (2016).

Hasil penelitian ini juga menunjukkan bahwa skor rerata CDMSE pada kelompok eksperimen mengalami penurunan pada pengukuran follow up. Hal ini menunjukkan efek pelatihan mengalami penurunan setelah satu bulan sejak perlakukan diberikan. Hal ini dimungkinkan terjadi penurunan efek pelatihan pada subjek. Menurut Marliani (20013) terdapat faktor eksternal yang dapat mempengaruhi validitas hasil penelitian dan hal itu diluar kendali peneliti. Faktor eksternal itu dapat berupa variabel non eksperimen seperti faktor dari individu, lingkungan atau tempat tinggal dan temperatur. Selain itu hasil penelitian juga menunjukkan peningkatan skor rerata CDMSE pada kelompok kontrol, meskipun peningkatan yang terjadi tidak siginifikan. Hal ini dimungkinkan terjadi karena adanya interaksi antara kelompok kontrol dengan kelompok eskperimen setelah perlakukan diberikan kepada kelompok eksperimen yang terjadi di laur kontrol peneliti. Penelitian juga memiliki keterbatasan adanya perbedaan antara jumlah kelompok eksperimen dan kelompok kontrol karena gugur pada beberapa tahap penelitian dilakukan. Penelitian selanjutnya dapat melakukan upaya antisipasi untuk mempertahankan jumlah subjek selama penelitian dilakukan

\section{Simpulan}

Berdasarkan hasil analisis data penelitian maka dapat diambil kesimpulan bahwa pelatihan perencanaan karir meningkatkan CDMSE pada siswa SMK. Pelatihan perencanaan karir memberikan pemahaman yang membangun kesadaran siswa mengenai potensi dan keterbatasan diri, memberikan pemahaman mengenai berbagai alternatif peluang karir serta memiliki keterampilan dalam menentukan pilihan karir. Hal tersebut menjadi dasar dalam menyusun rencana tindakan yang dibutuhkan untuk mencapai tujuan karirnya. Kejelasan informasi dan pertimbangan atas keuntungan dan potensi hambatan serta perencanaan yang jelas meningkatkan keyakinan pada siswa mengenai pilihan karirnya. Penelitian selanjutnya dapat melakukan upaya antisipasi untuk mempertahankan jumlah subjek selama penelitian dilakukan. Hasil penelitian juga menujukkan adanya penurunan efek intervensi setelah intervensi diberikan, penelitian selanjutnya dapat 
merancang intervensi yang berdampak jangka panjang. Penelitian berikutnya juga perlu melakukan kontrol terhadap variabel-variabel lain yang mungkin mempengaruhi efektivitas perlakuan yang tidak dilakukan dalam penelitian ini. Hasil penelitian ini juga dapat digunakan sebagai dasar bagi institusi untuk merancang program pengembangan atau pendidikan karir bagi siswa untuk membantu siswa dalam perencanaan karirnya.

\section{Daftar Pustaka}

Antoniu, E. (2010). Career planning process and its role in human resource development. Annals of the University of Petroşani, Economics, 10(2), 13-22

Ariani, N.W.T. (2016). Pengaruh pelatihan "PLANS" terhadap efikasi diri dalam pengambilan keputusan karir pada siswa SMK Tesis. Fakultas Psikologi Universitas Gadjah Mada.

Bandura, A. (1977). Self-efficacy: Toward a unifying theory of behavioral change. Psychological Review, 84,191-215.

Baruch, Y. (2004). Managing careers theory and practice. London: Pearson Education

Bardick, A.D., Berrnes, K. B., Magnusson, K.C., \& Witko, K.D. (2004) Junior High Career Planning: What Students Want. Canadian Journal of Counselling, 38:2, 104 $-117$.

Betz, N.E. \& Luzzo, D. (1996). Career assessment and the Career Decision-Making SelfEfficacy Scale. Journal of Career Assessment, 4, 313-328.

Betz, N. E. \& Taylor, K. M. (2012). Career Decision Self-Efficacy Scale and Short Form and Manual. Menlo Park, CA: Mind Garden, Inc.

Caprara, G. V., Scabini, E. \& Regalia, C. (2006). The impact of perceived family efficacy beliefs on adolescent development. In F. Pajares \& T. Urdan (Eds.). Self-Efficacy Beliefs of Adolescents. Connecticut: Information Age Publishing, Inc

Gushue, G,V., Scanlan, K.R.L., Pantzer, K.M., \& Clarke, C.P. (2006). The relationship of career decision-making self-efficacy, vocational identity, and career exploration behavior in African American high school students. Journal of career Development, 33(1), 19-28.

Fukuyama, M.A., Probert, B.S., Neimeyer,G.J., Nevill, D.D., \& Metzler, A.E. (1988). Effects of DISCOVER on career self- efficacy and decision-making of undergraduates. The Career Development Quarterly, 37,56-62.

Hurlock, E.B. (1994). Psikologi perkembangan suatu pendekatan sepanjang rentang kehidupan. Ed 6. Jakarta: Erlangga.

Juwitaningrum, I. (2013). Program bimbingan karir untuk mningkatkan kematangan karir siswa SMK. Psikopedagogia Jurnal Bimbingan dan Konseling 2013, vol 2, no 2, 1 16 
Kraus,L.J., \& Hughey, K.F. (1999). The impact of an intervention on career decisionmaking self-efficacy and career indecision. Profesional School Counseling, 2, 384390.

Manolescu, A. (2003) Human Resource Management, 4th Edition, The Economic Publishing House, Bucarest, p.332

Matsui, T. and Onglatco, M. L. (1992), "Career self -efficacy as a moderator of the relation between occupational stress and strain", Journal of Vocational Behavior, Vol. 41, pp. 79-88.

Marliani, R. (2013). Hubungan antara religiusitas dengan orientasi masa depan. Jurnal Psikologi, 9 (2), 130-137.

Mau, W. C., Hitchcock, R., \& Calvert, C. (1998). High school students' career plans: The influence of others' expectations. Professional School Counseling, 2, 161-166.

Purnamasari, A. (2006). Efektivitas pelatihan perencanaan karir untuk meningkatkan kejelasan arah pilihan bidang minat karir pada mahasiswa semester III Fakultas Psikologi. Humanitas Journal Vol. 3 No. 1 Januari 2006: 38 - 49

Riggio, R. E. (2003). Introduction to industrial/organizational psychology. California: Pearson Prentice Hall

Sawitri, D. R. (2009). Pengaruh status identitas dan efikasi diri keputusan karir terhadap keraguan mengambil keputusan karir pada mahasiswa tahun pertama di universitas diponegoro. Jurnal Psikologi Undip, 5(2), halaman tidak tercantum.

Schwarzer, R., \& Hallum, S. (2008). Perceived teacher self-efficacy as a predictor of job stress and burnout: Mediation analyses. Applied Psychology, 57 (s 1), 152-171.

Seo, Y \& Jeong, C. (2016). Effect of career coaching program for career decision making self efficacy, self-leadership,and employment-stress of nursing student. Journal of the Korea Academia-Industrial Cooperation Societ, 17(12), 138 - 145.

Taylor, K.M., \& Popma, J. (1990). An examination of the relationship among career decision-making self-efficacy, career salience, locus of control, and vocational indecision. Journal of Vocational Behavior, 37(1), 17-31

Wang, J., Zang, D., dan Shao, J. (2010). Group training on the improvement of college student's career decision-making self-efficacy. Retried from http://www.scirp.org/journal/HEALTH

Ziebell, J. L. C. (2010). Promoting viable career choice goals through career decision making self efficacy and career maturity in inner-city high school students: a test of social cognitive career theory (Disertasi). The University of Minnesota. 